\title{
技術動 向
}

\section{ポリペプチドと熱可塑性樹脂からなる ポリマーブレンドの製造と艺の性質}

大屋 正尚

1.はじめに

高分子物質に他の物質を混合してその性質を改良する ことは、ゴムにカーボンブラッタ，硝酸繊維素に樟脳と いった具合に，学れらの工業か成立した当初，というよ りあむしろ湿合の技術が開発されたために。工業化が成

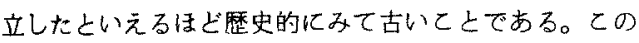
他，縮合采合成樹脂の分野では，フエノールーホルマリ ン樹能の初期縮合物化他のあのを湿合して硬化させるこ とが現在で旮行なわれている。

現在いわれているポリマーブレンドすなわち，二喠 類以上の高分子物質を混合して，各々の持っている特質 (特に物理的性質)を強く発揮させる改質の試みは，各種 の合成高分子が大量に生産され，利用ざれるようになっ てからのととである。

同じ系統の高分子物質で，結晶性，分子量の異なった あのを混合するととは，使用目的によって一定の弾性と 剛性の割合を必要とするゴム工業や，最近では包装フィ ルム等の分野で発展の目覚しいポリエチレン系の工業に おいて盛んに行なわれ，また，巽種の高分子物質を混合し， それぞれの持ち味を生かしたものを作ることは，ポリ塩 化ビニルを始めとするビ二ル系合成樹脂，アクリル酸エ ステル樹脂，ポリカーボナート、等はもとより弗素系樹脂 の分野においても行なわれ，単量体を湿合して高分子を 作る共重合上共任重要な一分野を占好るに至っている。

ポリマーブレンドの性質は混合する相互のポリマーの 溶解性によって決まる。との点ブロック共重合体やグラ フト重合体を構成するポリマ一の溶解性と性質の関係と よく似ている。相異点结前者は原則として相互のポリマ 一の間に共有結合のような化学結合は存在しないか，後 者は相互のポリマー銷が化学的汇結合していないという。

Preparation and Properties of Polymer Blends Consisting of a Polypeptide and a Thermoplastic MASANAO OYA

Department of Chemistry, College of Technology, Gunma University

群馬大学工業短期大学部工業化学科 教授 (工博)

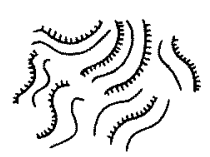

(A)

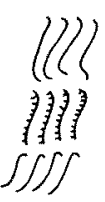

(c)
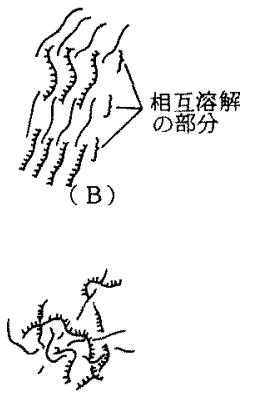

( D)
図 1 ポリマーブレンドの模式図

（A）乎ポリマーが相互に上く溶解する場合

(B) 雨㑐》ーの一部か愘解する場合

(C) 両ポリマーが䋉解しない場合

（D）両ポリマーが溶解しないが絡み合って いる場台

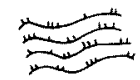

(A)
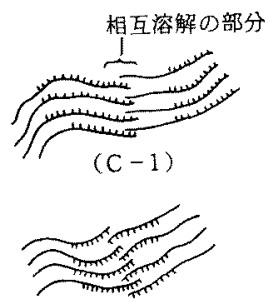

$(\mathrm{C}-2)$

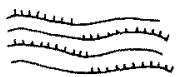

(B)

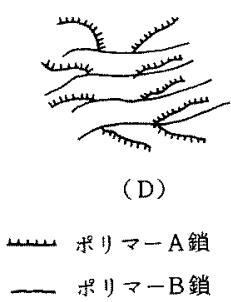

四 2 共重合, グラフト、ブロック共重合ポリマー の模式図

(A) ランダム共重合体

（B）ブロック共重合体で面术りマーがよく溶解する場合

( C - 1 ) 同しく雨椋リマーの一部溶解古る場合

(C-2) 同じく雨术リマーが熔解しない場合

(D) グラフト共重合体 
点である(図1，図2)。

ポリマーを混合(プレンド)する場合に，両ポリマーが 相互によく溶解する場合(図1-A)は同じ平均組成のポり マーからなる共重合体(図2-A，B）とよく似た性質のも のとなるため，両ポリマーの性質加らポリマーブレンド の性犋を予測することは困難である。

両ポリマーが相互に僅か儿溶解する場合(図1-B) 界 面で相互のポリマー間に接着がおこるから，両ポリマー の性筧を萧ね具えたポリマーブレンドが得られ，その性 質も両ポリマーの性質から予測できる。以上に述へた二 つの例の場合には两ポリマーの化学的な構造がある程度 似ているとよが必要である。両ポリマーの化学的構造が 全く異なる場合，たとえば，親水性の基をすち，水に溶 解したりり，吸湿したりする(天然瀻維)性質を持つもの之， 㻋水性の基を持って拈り，水に不溶で無極性または半極 性の有機溶媒に、膨潤または溶解するもの(ポリエチレン ポリ塩化ビニル，合成ゴム)とを泥合するととはできな い。仮に覑理に混合したとしても(図1-C)，物性の劣 ったものしか得られない。現在のところ異なった性質を 兼ね具えたポリマーを作るためには，グラフト共重合体 かブロック共重合体を合成する他はない(図2-C，D）。

ポリマーブレンドを作る場合には，両ポリマーの物理 化学的性質 (溶解性)と涺合上小う機械的操作が重要であ り、グラフト，ブロック共重合体を製造する場合には、 単量体の反纫性とその反応を調節する操作が重要である。 勿諭ブレンドの場合も，両ポリマーの分子間に化学的結 合のおとる場合もある。

相互にほとんど溶解しない二種のポリマー鎖が，末端 で化学的に結合しているブロックコポリマー(図 2-C2)では，敞小な分子の集合体のレベルでは相分離をおこ しているが，合成中に両ポリマー銷がからみ合っている とも考えられるし，また同種のポリマー銷が会合してい るともみられるので，巨視的には湿合しているとみてよ 以(図 2-C-2)。

ポリマーブレンドの場合にあ，全く相互に溶解しない 両ポリマーが分子状で相互にからまっていた場合(図 1 D)，相分離はおきないのではないかという考えも生じ る。すなわち,ポリプロピレンのように眯水性の繊維之 綿のように親水性の繊維を混新した系を水の中に入れて す分離しないのと同じである。すしこの混紡系を粉末に して水の中に入れれば、ポリプロピレンは浮き，綿は沈 み，相分離する筈である。分子同士を加らませる方法の 一つとして一方のポリマーの存在に他のモノマーを入れ 重合させることが考えられる。

今日まで行なわれて来たポリマーブレンドの主な目的 は，衝撃強度のような強度的性㥽の改良が主な目的であ
った。よって，泥合する相手ポリマーすある程度决って おり，全く相溶性のないポリマー同士のブレントは、 まり考えられなかった。しかし，高分子工業の発展に伴 ない利用分野が拡大され，それぞれの目的に応じた多粎 な性質が要求されることから，ポリマーブレントはは，多 様な性㨁を与えるための手段の一つと考えてもよい。

とのような考えから，ポリペプチドと，熱可塑性臌脂 とからなるポリマーブレンドを作ることあ興味あるすの 亡思われる。

\section{2. ポリペプチドと熱可塑性樹脂とからなる ポリマーブレンド}

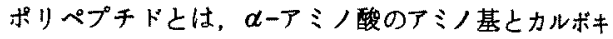
シル基が，脱水縮合して線状に結合した高分子物質をい い，絹，羊毛を始めとする天然タンパク質はこれに属す る。天然タンパク質は 28 㮔類余りの の順序に，固有の数結合しているから，タンパク質の瘇 類は無数にあるといってよい(式 1-(5))。

ポリペプチドを化学的に合成するには，数多くの方法

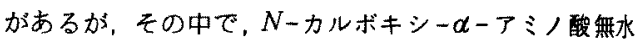
物 (NCA)を経由する方法が，高分子量のあのを，大量 に合成する方法としては適しており，一部のー $\alpha$ アミ 酸透或体(グルタミン酸エステル)は企業化されている。 この方法では，せいぜい三種類程度のアミノ酸を不規則 に結合するととしかできないが，タンパク質のモデルと

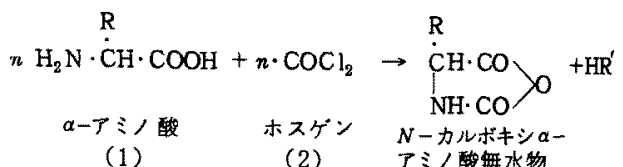
(3)<smiles>[R]C(NCC)C(=O)OOC(=O)C([R])NCC(=O)[O-]</smiles>

(4)<smiles>[R]C(N)C(=O)NC([R2])C([Y7])C(=O)NC(=O)OC(=O)CO</smiles>
(5)

使用した $\alpha$ アミノ酸

$$
\begin{aligned}
& \mathrm{R}=\frac{\mathrm{CH}_{8}}{\mathrm{CH}_{8}}>\mathrm{CH}-\mathrm{CH}_{2}-\quad \text { ロイシン } \\
& \mathrm{R}=\mathrm{C}_{6} \mathrm{H}_{6}-\mathrm{CH}_{2}-\quad \text { フエニルアラニン } \\
& \mathrm{R}=\stackrel{\mathrm{CH}_{8}}{\mathrm{CH}_{8}}>\mathrm{CH}-\quad \text { NIリン } \\
& \mathrm{R}=\mathrm{COOH} \quad \text { グルタミン酸 } \\
& \mathrm{CH}_{2}-\mathrm{CH}_{2}-
\end{aligned}
$$

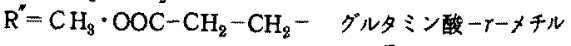

$$
\begin{aligned}
& \mathrm{R}^{\prime \prime}=\mathrm{C}_{8} \mathrm{H}_{6} \cdot \mathrm{CH}_{3} \cdot \mathrm{OOC}-\mathrm{CH}_{2}-\mathrm{CH}_{2}-\text { グルタミン酷-7- } \\
& \mathrm{R}^{\prime \prime} \text { ․天然に存在しない。 }
\end{aligned}
$$


して広く研究に利用されている(式1）。との分野での研 究が進むにつれて，合成ポリペプチドのフィルムが興味 ある性質を持っていることがわかり，膜として利用しよ うと試みられているい2)。しかし，ポリペプチドはごく 一部を除いては，工業的便用できる溶媒には溶解しな

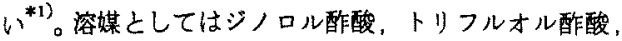
他弗素系の溶媒化溶解するが，乙れらのあのは，酸性が 強く，高価であり，しかも毒性も強いといわれているた め，ポリペプチドの単独フイルムを大量に作ることは困

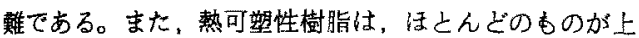
記のポリペプチドの溶媒には溶解しない。さらに，ポリ ペプチドは，軟化点附近で分解してしまうため，ポリぺ プチドと熱可塑性樹脂とのポリマーブレンドを作ること には，一般のポリマーブレンドを作る方法，すなわち， 両ポリマーを軟化点以上の温度でねり合わせる方法も， 共通溶媒江溶解して混合し，溶媒を除く方法の何れも適 用できない。ポリペプ手ドの溶媒である，トリフルオル 酶酸と熱可塑性樹脂，たとえばポリカーボナ一ト等の溶 媒である塩化メチレンはよく混合するが 各々溶液を混 合する之相分離を抬てし，強く擋柈して乳溜状のもの加 らフイルムを作っても極めて弱いものしかできない。
塩化メチレン、ジオキサン．工業的比利用され，しか も熱可塑性樹脂の溶媒之よく混合する溶媒を用いて, NCAの重縮合（式 1，(1) （4)）を行なうとき，均一系に近 い状態で反応が進行し、コロイド状ないしはゲル状の溶 液となる。しかし，ての采加ら溶媒を除去して一旦ポリ ペプチドを取出すと，二度とをの溶媒溶解しない場合 が多い。とれが合成ポリペプチドと他の植脂との違いで ある。そとで，NCA と熱可塑性樹脂とを共通溶媒に溶 解し，その状態でNCAを重縮合させれば，NCAの重縮 合に伴ってポリペプチド銷が生長するとき，熱可塑性樹 脂のポリマー銷にからまって重綟合し，図 2 Dのような ポリマーブレンドが合成できるとの予想の下にこの方法 を試みた。結果は表 1 ー ろに示した

混合溶液中のNCAの重鏥合が進行する上，溶液の透 明度がほ上んど变らない煬合と，乳濁状となる場合があ るが、いずれの場合屯粘度は上昇し，重縮合反応が終っ た系はコロイド状ないしはゲル状になる。ての湿合溶液 は非常に安定で，数ヶ月置いても，相分離しない場合が 多く，てのポリマーブレンドを一旦系から分離してあ， 同じ溶媒に再溶解ができる場合が多い。このととは，こ のブレンド中で，ポリペプチドはあまり分子会合してい

表1 ポリペプチドと熱可塑性樹脂とからなるポリマーブレンドの製造とその性質 (I)

\begin{tabular}{|c|c|c|c|c|c|c|c|c|c|}
\hline No. & 熱可塑性樹脂 & (g) & 溶 & $(\mathrm{ml})$ & $a-ア ミ$ 酸 NCA (g) & $\begin{array}{l}\text { フイル } \\
\text { 透明度 (另) }\end{array}$ & $\begin{array}{l}\text { 厚 d } \\
(\mathrm{mm})\end{array}$ & $\begin{array}{l}\text { 強 } \text { 度 }^{2} \\
\mathrm{~kg} / \mathrm{mm}^{2}\end{array}$ & $\begin{array}{c}\text { 伸 度 } \\
(\text { 多 })\end{array}$ \\
\hline $1 \mathrm{~A}$ & ポリカーボナート & 1 & 簤化メチレン & 20 & L-ロイシン & 40 & 0.06 & $\cdots$ & $* * 1)$ \\
\hline $1 \mathrm{~B}$ & " & 1 & $"$ & 20 & $\mathrm{~L}$ ーエニルアラニン 0.7 & 20 & 0.06 & ... & $* * 1)$ \\
\hline $1 \mathrm{C}$ & $"$ & 1 & $"$ & 20 & $\begin{array}{l}r \text { ダンジルLーグル } \\
\text { タメート }\end{array}$ & 80 & 0.1 & 2.2 & $5^{* * 2)}$ \\
\hline $2 \mathrm{~A}$ & ポリスルホン & 1 & 程化メチレン & 20 & 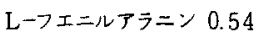 & 80 & 0.07 & $\cdots$ & $* * 1)$ \\
\hline $2 \mathrm{~F}$ & " & 1 & $\prime \prime$ & 20 & 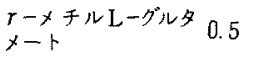 & 40 & 0.1 & 0.15 & $13^{* * 3)}$ \\
\hline 3 & ポリクロロプレン & 1 & $"$ & 20 & Lーバリン & $\cdots$ & $\cdots$ & $\cdots$ & $* * 3)$ \\
\hline 4 & エチル繀維素 & 1 & $"$ & 20 & $\mathrm{~L} ー$ フエニルナラニン 0.5 & 80 & 0.05 & & $* * 1)$ \\
\hline $4 \mathrm{~F}$ & " & 1 & $"$ & 20 & $\begin{array}{l}\text { マーメチルL-ダルタ } 0.5 \\
x ー ト\end{array}$ & 60 & 0.1 & 0.4 & $15^{* * 1\}}$ \\
\hline
\end{tabular}

NCA 熱可塑性榼脂混合溶液を次の条件で重合した捘フイルムに成型した。

**1）開始剂： $n$ ーブチルアミンNCAに奶し0.1 mol\%，20C，336 時間

**2）開始剂加えず 15 C 216 時間

**3) 䦩始剂加元式 $25 \mathrm{C} \quad 144$ 時間

構造式 ポリカーボナート (

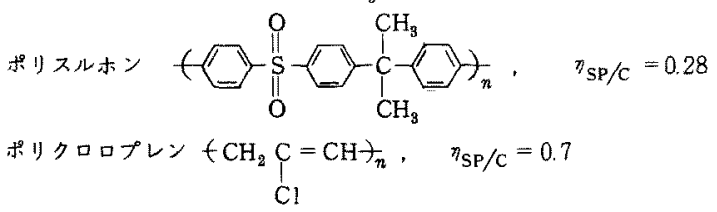

${ }^{n} \mathrm{SP} / \mathrm{C} \quad \mathrm{C}=0.5 \mathrm{~g} / 100 \mathrm{ml}$ 塩化メチレン中 $25^{\circ} \mathrm{C}$

*1) 共重合ポリペプチドはジメチルホルムアミド、ジクロルエタンに容解する場合すある。 
表 2 ポリペプチドと熱可塑性樹脂とからなるポリマーブレンド の製造とその性質 (II) $\left.{ }^{* 1}\right)$

\begin{tabular}{|c|c|c|c|c|c|c|c|c|}
\hline No. & 熱可塑性樹脂 ( & & 溶 & 媒 $(\mathrm{ml})$ & & $\begin{array}{c}\alpha-\mathrm{\gamma} \text { ミ } / \text { 酸 }(\mathrm{g}) \\
\mathrm{NCA}\end{array}$ & $\begin{array}{l}\text { フイルムの } \\
\text { 透明度 (\%) }\end{array}$ & $\begin{array}{l}\text { 厚 } \\
(\mathrm{mm})\end{array}$ \\
\hline $1 \mathrm{G}$ & ポリカーボナート & 1 & ジクロル & エタン & 20 & DLーロイシン 0.4 & 40 & 0.2 \\
\hline $1 \mathrm{H}$ & $" \prime$ & 1 & $"$ & & 20 & DLーバリン 0.4 & 60 & 0.15 \\
\hline $3 \mathrm{G}$ & ポリクロロプレン & 1 & ジクロル & エタン & 20 & DL-ロイシン 0.4 & 60 & 0.08 \\
\hline $3 \mathrm{H}$ & $" \prime$ & 1 & $" \prime$ & & 20 & DLーバリン 0.4 & 60 & 0.08 \\
\hline $4 \mathrm{G}$ & エチル㵶維素 & 1 & ジクロル & エタン & 20 & DLーロイシン 0.4 & 70 & 0.03 \\
\hline $4 \mathrm{H}$ & $"$ & 1 & $"$ & & 20 & DLーバリン 0.4 & 90 & 0.04 \\
\hline $5 \mathrm{G}^{* 2)}$ & ポリ塩化ビニル & 1 & テトラヒト & ドロフラン & 20 & DL-ロイシン 0.4 & 70 & 0.05 \\
\hline $5 \mathrm{H}$ & $"$ & 1 & $"$ & & 20 & DLーバリン 0.4 & 45 & 0.06 . \\
\hline
\end{tabular}

表 3 ポリペプチドと熱可塑性樹脂からなるポリマーブレンド の製造之性買 (III) 製造法の相違による性質の違い

（A） NCAを混合直後フイルムを作り，NCAをフイルム状で重合した場合

\begin{tabular}{cccccccr}
\hline No. & $\begin{array}{c}\text { ポリ塩化ビニル } \\
(\mathrm{g})\end{array}$ & $\begin{array}{c}\text { 溶 } \\
\text { テトラヒドロフラン }\end{array}$ & $\begin{array}{c}\text { L-ロイシン } \\
\text { NCA }(\mathrm{g})\end{array}$ & $\begin{array}{c}\text { フイム透明度 } \\
(\%)\end{array}$ & $\begin{array}{c}\text { 厚 さ } \\
(\mathrm{mm})\end{array}$ & $\begin{array}{c}\text { 強 } \\
\mathrm{kg} / \mathrm{mm}^{2}\end{array}$ & $\begin{array}{r}\text { 伸 度 } \\
(\%)\end{array}$ \\
\hline 1 & 1 & 40 & 1 & 55 & 0.04 & 0.7 & 6 \\
2 & 1 & 40 & 0.7 & 75 & 0.02 & 1.5 & 4 \\
3 & 1 & 40 & 0.5 & 80 & 0.03 & 1.2 & 8 \\
4 & 1 & 40 & 0.25 & 75 & 0.03 & 1.4 & 8 \\
5 & 1 & 40 & 0.13 & 75 & 0.01 & 1.4 & 11 \\
\hline
\end{tabular}

（B） NCAを混合し重縮合後にフイルムを作った場合

\begin{tabular}{|c|c|c|c|c|c|c|c|}
\hline No. & $\begin{array}{c}\text { ポリ塩化ビニル } \\
(\mathrm{g})\end{array}$ & $\begin{array}{l}\text { 溶媒（ml） } \\
\text { テトラヒドロフラン }\end{array}$ & $\begin{array}{r}\mathrm{L}-\text { ロイシン } \\
\mathrm{NCA}(\mathrm{g})\end{array}$ & $\begin{array}{c}\text { フイルム透明度 } \\
(\mathscr{6})\end{array}$ & $\begin{array}{l}\text { 厚 さ } \\
(\mathrm{mm})\end{array}$ & $\begin{array}{c}\text { 強 度 } \\
\mathrm{kg} / \mathrm{mm}^{2}\end{array}$ & $\begin{array}{c}\text { 伸 度 } \\
(\mathscr{8})\end{array}$ \\
\hline 1 & 1 & 40 & 1 & 25 & 0.1 & 0.3 & 4 \\
\hline 2 & 1 & 40 & 0.7 & 70 & 0.03 & 1.0 & 8 \\
\hline 3 & 1 & 40 & 0.5 & 80 & 0.02 & 1.5 & 9 \\
\hline 4 & 1 & 40 & 0.25 & 80 & 0.03 & 1.6 & 14 \\
\hline 5 & 1 & 40 & 0.13 & 85 & 0.03 & 1.6 & 8 \\
\hline
\end{tabular}

強，伸度，テンシロンUTM 2 型 $10 \mathrm{~mm}$ (幅) $\times 20 \mathrm{~mm}$ (長さ) 最大荷重 $2 \mathrm{~kg}$, 引張り速度 $40 \mathrm{~mm} /$ 分で測定。 伸度は降伏点のをれ。

ポリ塩化ビニル 重合度 2,500 ,引張り強度 $0.6 \mathrm{~kg} / \mathrm{mm}^{2}$, 伸度 $15 \%$, A B共に開始剂卜リエチルアミン

NCAに対し $0.5 \mathrm{~mol}$ 另加えた。（B） 30 Cで7日間重䊒合を行なった。

ないととを示唆する。予想通りポリペプチド鎖が生長す 際，熱可塑性樹脂の銷に絡まったため，このように安 定になったものと思われる。重繀合後の混合溶液が流動 性のある場合には，てれをガラス板上に流してフィルム を作ることができるが、ゲル状になる場合には NCA と 熱可塑性樹脂の混合溶液を容器に入れて NCAを重綰合 して後，溶媒を除去してフイルムを作るこしができる。 また，NCAを熱可塑性樹脂と混合溶解して，直ちにフィ ルムを作り、フイルム中でNCAの重縮合を行うこよが できる。LーバリンNCAを用いてポリーLーバリンを含む ポリマーブレンドを作るときにとの方法で好結果が得ら れる。
グリシンNCAはジメチルホルムアミド、ジメチルスル ホキシドのような極性の強い高沸点溶媒を除いては，溶 解度が極めて低いので，ポリグリシンと熱可塑性樹脂か らなるポリマーブレンドの合成は困難である。ポリーLアラニンを含むポリマーブレンドを合成する場合あ，L ーアラニンNCAの重縮合が進行するに伴って, 系が固 いゲル状になったり，ポリアラニンが沈殿する場合が多 く，条件の設定に笅密さが必要となる。

表 2 に示した例は，いずれあNCAを湿合淔後にフィ ルムを作り，フィルム中でNCAを重㩁合したものであ るが，何れの場合も，二週閶でNCAが完全にポリペプ チドになっていることがわかった。しかしフイルムの透 


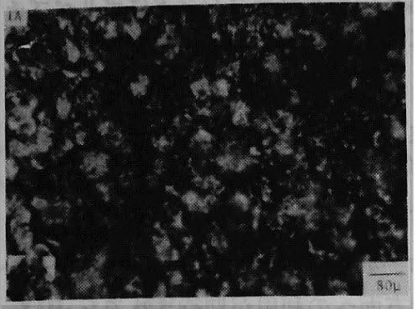

$1 \mathrm{~A}$

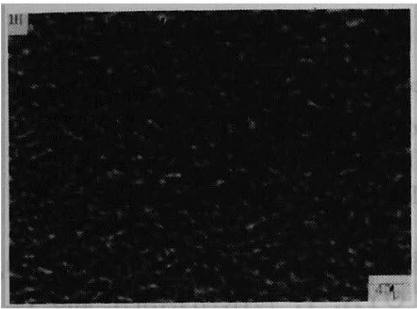

$1 \mathrm{H}$

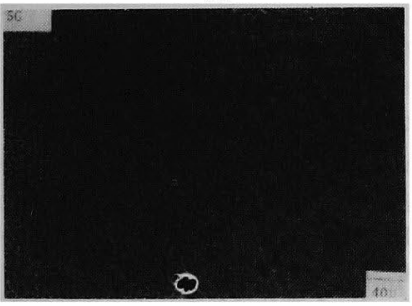

$5 \mathrm{G}$

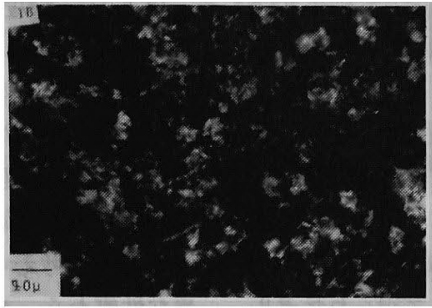

$1 \mathrm{~B}$

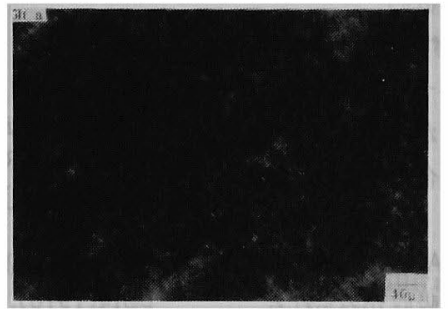

$3 \mathrm{H}$

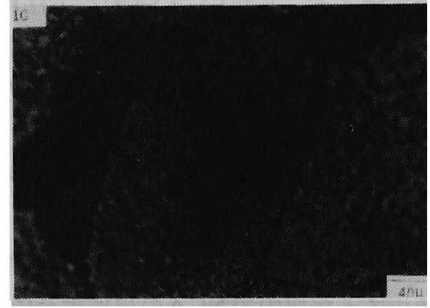

$1 \mathrm{G}$

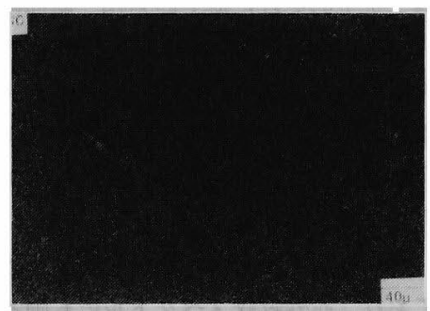

$4 \mathrm{G}$

偏光顕微鏡 $530 \mathrm{~m} \mu$ 鋭敏色を使用

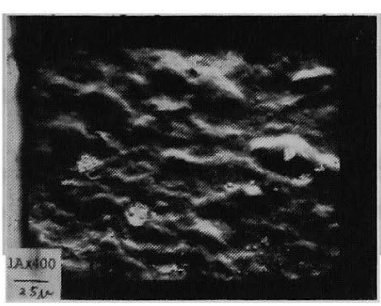

$1 \mathrm{~A}$

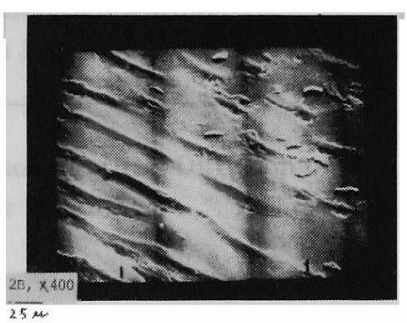

$2 \mathrm{~B}$

走査型電子顕微鏡

写真に示した番号は表 1 ～3に示した番号の同じフイルムの

写真であるととを示す。

図 3 ブレンドフイルムの偏光顕微鏡および走査型電子顕微鏡写真

明度はほとんど変化しない ${ }^{* 1)}$

表 3 はポリ塩化ビニルと, ポリーLーロイシンとのポリ マーブレンドを作るとき，ポリ塩化ビニルと， Lーロイ シンNCAを混合溶解した後，直ちにフイルムを作りフ イルム状でNCAを重縮合した場合と，NCAを重縮合し てからフイルムを作った場合とを比較した。”

*1）フイルムの透明度は赤外線の $4000 \mathrm{~cm}^{-1}$ の透過率を基準 とした。
両方法を比較すると，LーロイシンNCAの割合が多い No.1ではBの方がや〉透明度が少っているが，ポリ塩 化ビニル 1 に対して NCA 0.7 以下のものの透明度は何れ の方法によってあ優れている。純ポリ塩化ビニルフイル $ム^{* 1)}$ に比べて強度は高くなり，伸度は低下しているが， NCAの濃度の高い所では (No.1，No.2)Aの方が強度が 高い。このととはAの方が相互によく混合しているとと *1)シクロヘキサン溶液からフイルムを作ったもの。 
を示唆する。しかし、いずれの方法によっても両ポリマ 一から，ポリペプチドを分㸺するととは困難である。数 回，抽出や再沈殷を繰返して分離したポリペプチドは， NCAを単独で溶液重合した場合よりも粘度は低い。低 粘度のポリペプチドが分㒕したと考考えられるので。さ らに検討している。

ポリペプチドのブレンドフィルム中での二次構造は， 使用する溶媒中でNCAの単独重合によって得られたポり ペプチドのそれに似ているが，結晶性は低い。

NCAが熱可塑性樹脂共存下で重縮合する速度は相手 の樹脂の種類により異なり，ポリカーボナート．エチル 䄉維素では速く，ポリスルホンでは遲いが，グラフト重 合が拈てっているのか，マトリックス重合であるのかは。 今後の問題である。

ポリペプチドの含有量は混合したNCAの量に相当し ており，赤外吸収スペクトルにも正者の吸収がみられる。

ての上うにして作ったボリマーブレントの分散状態を 調へるため，フイルムの光学顕微鏡亡電子顕微鏡写真を 撮影した（図3)。

ポリーLーロイシン，ポリーLーフエニルアラニンは， ポリカーボナートやポリスルホンの中に球晶として分散 しているように思われるが，エチル繊維素中にはより微 紐な状態で分散している。

走查型電子顕微鏡写真からも。ポリーLーフエニルアラ ニン，ポリーLーロイシンは，ポリカーボナート中によく 分散しているととがわかるが、NCAの重合に祭しては， 重合結晶化 ${ }^{4)}$ が扎てっているととが示唆される。
以上のととから，とのポリマーブレンドはポリペプチ ドの徽粒子が周囲を熱可塑性樹脂俘支持され，固定化さ れているとみることができる。强度，酎衝整性の改善住 两ポリマーの相溶性から飛躍的改善は望めないかす知れ ないが、これを䑅として利用する場台，ポリペプキトと 熱可塑性樹脂の両方の性䨘を兼ねそなえたものとなるこ 之は容易に考えられ，ポリペプチドの酸素透過性等，特 異な性質加ら，この方面への利用が期待ざれる。

\section{女南}

1) E. KLEIN, P. D. MAY, J. K. SMITH, and LEGER, Biopolymers, 10, 647 (1971)

2) E. C. MARTIN, P. D. MAY, and W. A. McMAHON, J. BIOMED. MATER. RES. 5, 53 (1972)

3) 大屋正尚，高橋智子，独永安夫，日本化学羟誌，(4), p.614(1978).M. OYA, T. TAKAHASHI, and Y. SUNAGA, "PREPRINTS MACRO MAINZ" 3 (1979) p 1576.

阿部 夈、群馬大学工業短期大学部, 卒羓論文集.

4) T. KOMOTO, T. AKAISHI, M. ŌYA, and T, KAWAI, Macromol. Chem. 154, 151 (1972)

以上の他，次の著畫参照ざれたい。

1) LAURENCE E. NIELSEN，小野不 重治訉，

2) “高分子の力学的性㨁”化学同人，(東京) 1972 .

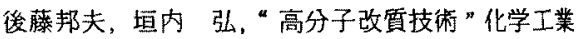
社 (東京) 1972 .

3) Plastic Age 編集委員会 "Plastic Age Encyclopedia” K.K.プラスチックエージ社 (東京) 1975. 